Soil Biology

Muhammad Zaffar Haśshmi - Ajit Varma Editors

Environmental

Pollution of

Paddy Soils

Springer 


\section{Soil Biology}

Volume 53

Series Editor

Ajit Varma, Amity Institute of Microbial Technology, Amity University Uttar Pradesh, Noida, UP, India 
More information about this series at http://www.springer.com/series/5138 
Muhammad Zaffar Hashmi • Ajit Varma

Editors

\section{Environmental Pollution of Paddy Soils}

囪 Springer 


\author{
Editors \\ Muhammad Zaffar Hashmi \\ Department of Meteorology \\ COMSATS University \\ Islamabad, Pakistan
}

\author{
Ajit Varma \\ Amity Institute of Microbial Technology \\ Amity University Uttar Pradesh \\ Noida, India
}

ISSN 1613-3382

Soil Biology

ISBN 978-3-319-93670-3

https://doi.org/10.1007/978-3-319-93671-0
ISSN 2196-4831 (electronic)

ISBN 978-3-319-93671-0 (eBook)

Library of Congress Control Number: 2018954502

(C) Springer International Publishing AG, part of Springer Nature 2018

This work is subject to copyright. All rights are reserved by the Publisher, whether the whole or part of the material is concerned, specifically the rights of translation, reprinting, reuse of illustrations, recitation, broadcasting, reproduction on microfilms or in any other physical way, and transmission or information storage and retrieval, electronic adaptation, computer software, or by similar or dissimilar methodology now known or hereafter developed.

The use of general descriptive names, registered names, trademarks, service marks, etc. in this publication does not imply, even in the absence of a specific statement, that such names are exempt from the relevant protective laws and regulations and therefore free for general use.

The publisher, the authors, and the editors are safe to assume that the advice and information in this book are believed to be true and accurate at the date of publication. Neither the publisher nor the authors or the editors give a warranty, express or implied, with respect to the material contained herein or for any errors or omissions that may have been made. The publisher remains neutral with regard to jurisdictional claims in published maps and institutional affiliations.

This Springer imprint is published by the registered company Springer Nature Switzerland AG The registered company address is: Gewerbestrasse 11, 6330 Cham, Switzerland 


\section{Contents}

1 Major Pollutants of Contaminated Paddy Soils . . . . . . . . . . . . . 1 Sunbal Siddique

2 Problems and Prospects of Cultivating Indigenous Flood and Brackish Water-Resistant Varieties of Paddy in the Context of Projected Sea Level Rise: A Case Study from Karnataka, India . . .

Tamoghna Acharyya and Manoranjan Mishra

3 Environmental Pollution of Soil and Anthropogenic Impact of Polymetallic Hydrothermal Extractions: Case Study-Bregalnica River Basin, Republic of Macedonia . . . . . . . . . . . . . . . . . . . 27

Biljana Balabanova, Trajče Stafilov, and Robert Šajn

4 Sources of Organochlorine Pesticidal Residues in the Paddy Fields Along the Ganga-Brahmaputra River Basin: Implications for Long-Range Atmospheric Transport . . . . . . . . . . . . . .

Paromita Chakraborty, Sanjenbam Nirmala Khuman, Bhupander Kumar, and Daniel Snow

5 Antibiotics Pollution in the Paddy Soil Environment . . . . . . . . . Vanessa Silva, Gilberto Igrejas, and Patrícia Poeta

6 Antibiotics and Resistant Genes in Paddy Soil Muhammad Afzaal, Safdar Ali Mirza, Miuniza Mir, Sarfraz Ahmed, Azhar Rasul, Shabab Nasir, Muhammad Yasir Waqas, and Ummad ud din Umar 
$7 \quad$ Paddy Land Pollutants and Their Role in Climate Change . . . . . . . 113

Rida Akram, Veysel Turan, Abdul Wahid, Muhammad Ijaz, Muhammad Adnan Shahid, Shoaib Kaleem, Abdul Hafeez, Muhammad Muddassar Maqbool, Hassan Javed Chaudhary, Muhammad Farooq Hussain Munis, Muhammad Mubeen, Naeem Sadiq, Rabbia Murtaza, Dildar Hussain Kazmi, Shaukat Ali, Naeem Khan, Syeda Refat Sultana, Shah Fahad, Asad Amin, and Wajid Nasim

8 Impact of Pollutants on Paddy Soil and Crop Quality . . . . . . . . . . . 125 Iftikhar Ali, Muhammad Jamil Khan, Mumtaz Khan, Farah Deeba, Haziq Hussain, Muhammad Abbas, and Muhammad Daud Khan

9 Paddy Soil Microbial Diversity and Enzymatic Activity in Relation to Pollution

Muhammad Afzaal, Sidra Mukhtar, Afifa Malik, Rabbia Murtaza, and Masooma Nazar

10 Arsenic in Paddy Soils and Potential Health Risk .

Bushra Afzal, Ishtiaque Hussain, and Abida Farooqi

11 Risk Assessment of Heavy Metal Contamination in Paddy Soil, Plants, and Grains (Oryza sativa L.) . . . . . . . . . . . . . . . . 165 Prasanti Mishra and Manoranjan Mishra

12 Arsenic in Untreated and Treated Manure: Sources, Biotransformation, and Environmental Risk in Application on Soils: A Review . . . . . . . . . . . . . . . . . . . . . . . . . . .

Muhammad Zaffar Hashmi, Aatika Kanwal,

Rabbia Murtaza, Sunbal Siddique, Xiaomei Su, Xianjin Tang, and Muhammad Afzaal

13 Fate of Organic and Inorganic Pollutants in Paddy Soils . . . . . . . .

Rida Akram, Veysel Turan, Hafiz Mohkum Hammad,

Shakeel Ahmad, Sajjad Hussain, Ahmad Hasnain,

Muhammad Muddasar Maqbool, Muhammad Ishaq Asif Rehmani, Atta Rasool, Nasir Masood, Faisal Mahmood, Muhammad Mubeen, Syeda Refat Sultana, Shah Fahad, Khizer Amanet, Mazhar Saleem, Yasir Abbas, Haji Muhammad Akhtar, Sajjad Hussain, Farhat Waseem, Rabbia Murtaza, Asad Amin, Syed Ahsan Zahoor, Muhammad Sami ul Din, and Wajid Nasim

14 Tolerance Mechanisms of Rice to Arsenic Stress . . . . . . . . . . . . . 215 Shahida Shaheen and Qaisar Mahmood

15 Enzymes' Role in Bioremediation of Contaminated Paddy Soil . . . . 229 Niharika Chandra, Swati Srivastava, Ankita Srivastava, and Sunil Kumar

16 Bioremediation of Contaminated Paddy Soil .

Naseer Ali Shah, Imdad Kaleem, Asghar Shabbir, Sadaf Moneeba, and Ayesha Hammed Khattak 


\title{
Chapter 3 \\ Environmental Pollution of Soil \\ and Anthropogenic Impact of Polymetallic \\ Hydrothermal Extractions: Case Study- \\ Bregalnica River Basin, Republic \\ of Macedonia
}

\author{
Biljana Balabanova, Trajče Stafilov, and Robert Šajn
}

\subsection{Introduction}

The distribution of certain chemical elements, which in higher contents represent hazard to the environment, causes certain unwanted consequences on human health (Brulle and Pellow 2006; Duruibe et al. 2007). Pollution of the environment with toxic metals has been topic of numerous studies which specify as their main subject matter the industrialized areas, the areas where exploitation and processing of natural resources (oil, ore, etc.) take place or highly populated areas where the traffic and communal waste represent the main sources of metals (Alloway and Ayres 1997; Siegel 2002; Järup 2003).

The exploitation of mineral resources by man leads to excavation, separation, transportation and dispersion of the metals contained in the fine dust (microparticles). In this way the metals are introduced into the environment in much greater contents than normally found in nature (Sengupta 1993; Salomons 1995). With the passage of time and the long-term activities of the human factor, the contents of certain metals have been completely and permanently changed in relation to their natural existence in the environment. These changes can have a significant influence

\footnotetext{
B. Balabanova $(\bowtie)$

Faculty of Agriculture, University “Goce Delčev”, Štip, Republic of Macedonia

e-mail: biljana.balabanova@ugd.edu.mk

T. Stafilov

Faculty of Science, Institute of Chemistry, Ss. Cyril and Methodius University, Skopje,

Macedonia

e-mail: trajcest@pmf.ukim.mk

R. Šajn

Geological Survey of Slovenia, Ljubljana, Slovenia

e-mail: robert.sajn@geo-zs.si
} 